\title{
Studi Kelajuan Elektrolit Terhadap Kapasitas Baterai Dinamis Asam Timbal Sel Tunggal
}

\author{
Muhammad Ghufron ${ }^{1}$, Istiroyah ${ }^{2}$, Cholisina A. Perwita ${ }^{3}$, Levinus Gobay ${ }^{4}$, Fakhrusy \\ Rizki Ramadhan ${ }^{5}$, Kurriawan Budi Pranata ${ }^{6}$ \\ 1,2,3 Program Studi Fisika, Fakultas Matematika dan Ilmu Pengetahuan Alam, Universitas Brawijaya, \\ Jalan Veterang Malang 65145, Indonesia \\ ${ }^{4,5}$ Alumni Program Studi Fisika, Fakultas Matematika dan Ilmu Pengetahuan Alam, Universitas \\ Brawijaya, Jalan Veterang Malang 65145, Indonesia \\ ${ }^{6}$ Program Studi Pendidikan Fisika, Universitas Kanjuruhan Malang, Malang, Indonesia \\ Email:mghufron@ub.ac.id
}

\begin{abstract}
Electrolyte flow rate is one of the important parameters on Redox Flow Battery (RFB) performance. A single cell lead acid battery has been made with the RFB system by giving 4 variations in flow speed $(45 \mathrm{~mL} / \mathrm{min}, 77 \mathrm{~mL} / \mathrm{min}, 90 \mathrm{~mL} / \mathrm{min}$ and $105 \mathrm{~mL} / \mathrm{min}$ ), two electrolyte concentrations (30\% and $40 \%)$ and applied $1 \mathrm{~A}$ of charging-discharging current with the aim of an88ukmalyzing the relationship of the electrolyte flow rate of the battery to the RFB system capacity. The results showed that the flow of electrolytes from tanks outside the cell battery was able to increase battery capacity by increasing the number of spontaneous redox reactions during charging and discharging. The cycle time and battery capacity increase at the beginning of the filling-emptying cycle but have a downward trend with the increasing number of cycles. Batteries with an electrolyte concentration of $30 \%$ and speeds of $90 \mathrm{~mL} / \mathrm{mnt}$ have the best performance in terms of discharging capacity compared to other batteries.
\end{abstract}

Keywords: Lead-Acid, Renewable energy, Electrolyte flowrate, Capacity, Battery

\begin{abstract}
Abstrak: Laju aliran elektrolit adalah salah satu parameter penting pada kinerja Redox Flow Battery (RFB). Baterai asam timbal sel tunggal telah dibuat dengan sistem RFB dengan memberikan 4 variasi kelajuan aliran ( $45 \mathrm{~mL} / \mathrm{mnt}, 77 \mathrm{~mL} / \mathrm{mnt}, 90 \mathrm{~mL} / \mathrm{mnt}$ dan $105 \mathrm{~mL} / \mathrm{mnt})$, dua konsentrasi elektrolit (30\% dan $40 \%$ ) dan diterapkan $1 \mathrm{~A}$ arus pengisian-pemakaian dengan tujuan menganalisis hubungan laju aliran elektrolit baterai dengan kapasitas sistem RFB. Hasil penelitian menunjukkan bahwa aliran elektrolit dari tangki di luar baterai sel mampu meningkatkan kapasitas baterai dengan meningkatkan jumlah reaksi redoks spontan selama pengisian dan pemakaian. Waktu siklus dan kapasitas baterai meningkat pada awal siklus pengisian-pengosongan tetapi memiliki tren menurun dengan meningkatnya jumlah siklus. Baterai dengan konsentrasi elektrolit 30\% dan kelajuan $90 \mathrm{~mL} / \mathrm{mnt}$ memiliki kinerja terbaik dalam hal kapasitas pemakaian dibandingkan baterai lainnya.
\end{abstract}

Kata kunci: Asam Timbal, Energi terbarukan, Laju elektrolit, Kapasitas, Baterai

\section{PENDAHULUAN}

Indonesia menempati peringkat pertama negara dengan konsumsi energi terbesar di ASEAN dan dengan pertumbuhan PDB di atas $6 \%$ masih akan terus meningkat jumlah konsumsi energinya hingga 2050, dimana hal ini sejalan dengan pertumbuhan konsumsi energi primer global yang selalu meningkat dalam 10 tahun terkahir dimana mencapai angka 2,9\% pada tahun 2018 [1-2]. Kebutuhan akan listrik perkapita dipercaya akan mencapai $4.902 \mathrm{kWh}$ pada tahun 2050, meningkat hampir 600\% bila dibandingkan tahun 2016 dengan angka $846 \mathrm{kWh} / \mathrm{kapita}$. Oleh karena itu, upaya pemerintah untuk meningkatkan penggunaan EBT (Energi Baru Terbarukan) mencapai $23 \%$ pada tahun 2025 terutama penggunaan sel surya perlu mendapat 
dukungan [2]. Baterai sebagai salah satu instrumen sel surya sebagai energy storage menjadi tema penting untuk dikembangkan dan terus ditingkatkan kemampuannya. Baterai dengan kemamampuan menyimpan muatan tinggi, mudah, murah dan bisa diisi ulang terus menjadi topik penelitian hingga saat ini [3] seperti penggunaan LiPoO4 [4], Vanadium [5], Nikel Cadmium [6] dan Asam timbal [7-10].

Baterai asam timbal berdasarkan perlakuan pada elektrolitnya dapat dibedakan menjadi baterai asam timbal statis (elektrolit diam) dan baterai asam timbal dinamis (elektrolit mengalir). Baterai dinamis atau lebih dikenal dengan Redox Flow Battery (RFB) untuk asam timbal (LARFB) mulai menjadi perhatian sejak Zhang dkk melaporkan bahwa RFB lead acid dapat menggunakan elektrolit tunggal (single electrolyte) dimana sebelumnya RFB banyak menggunakan dua elektrolit (double electrolyte) dalam sistem sel baterai [11]. Kelebihan yang diperoleh pada baterai asam timbal statis juga muncul pada asam timbal dinamis yakni mampu diisi ulang, murah, mudah dalam perawatan dan menghasilkan daya cukup tinggi. Penelitian terkait dengan baterai asam timbal telah banyak dilakukan dengan tujuan untuk meningkatkan performa baterai mulai dari peningkatan kualitas elektroda (modifikasi bentuk, pemurnian dan luas permukaan reaksi redox), penggunaan elektrolit yang berbeda dan konsentrasi berbeda. Asam timbal basah umumnya menggunakan 2 jenis elektrolit yakni asam sulfat [12] dan methansulfonic acid dengan hasil daya yang berbeda dimana penggunaan asam sulfat menghasilkan tegangan sekitar $2 \mathrm{~V}$ dan methansulfonic acid menghasilkan tegangan sekitar 1,6 $\mathrm{V}[13]$.

Pada baterai dinamis kelajuan aliran elektrolit menjadi komponen penting dalam menghasilkan densitas muatan yang tinggi namun penelitian terkait dengan hal ini masih terbatas. Kelajuan elektrolit akan berkontribusi pada energi awal yang dimiliki oleh ion-ion elektrolit dan berdampak pada laju reaksi antara elektroda dan elektrolit. Hal ini menyebabkan jumlah muatan yang dihasilkan oleh baterai berkorelasi secara nyata pada kecepatan elektrolit. Berkaitan dengan hal tersebut pada penelitian ini bertujuan untuk melakukan analisis pengaruh kelajuan elektrolit asam sulfat terhadap kapasitas baterai asam timbal dinamis dan grafik tegangan selama siklus pengisian-pengosongan dihasilkan dengan menggunakan parameter arus konstan.

\section{METODE PENELITIAN}

Pembuatan sistem baterai asam timbal dinamis sel tunggal dilakukan dengan modifikasi baterai asam timbal 6 sel dipasaran. Baterai asam timbal 6 sel dengan label kapasitas $5000 \mathrm{mAh}$ dipakai hanya $1 \mathrm{sel}$ (tanpa tahu nilai kapasitas persel) dengan ukuran masing lempeng elektroda $4,5 \times 7,5 \mathrm{~cm} 2$ kemudian ditaruh wadah plastik yang telah diintegrasikan dengan pompa peristaltik untuk mengalirkan elektrolit dari tanki di luar sel dan turnigy accucell-6 sebagai instrumen pengambil data karakteristik baterai secara kontinyu dan realtime. 


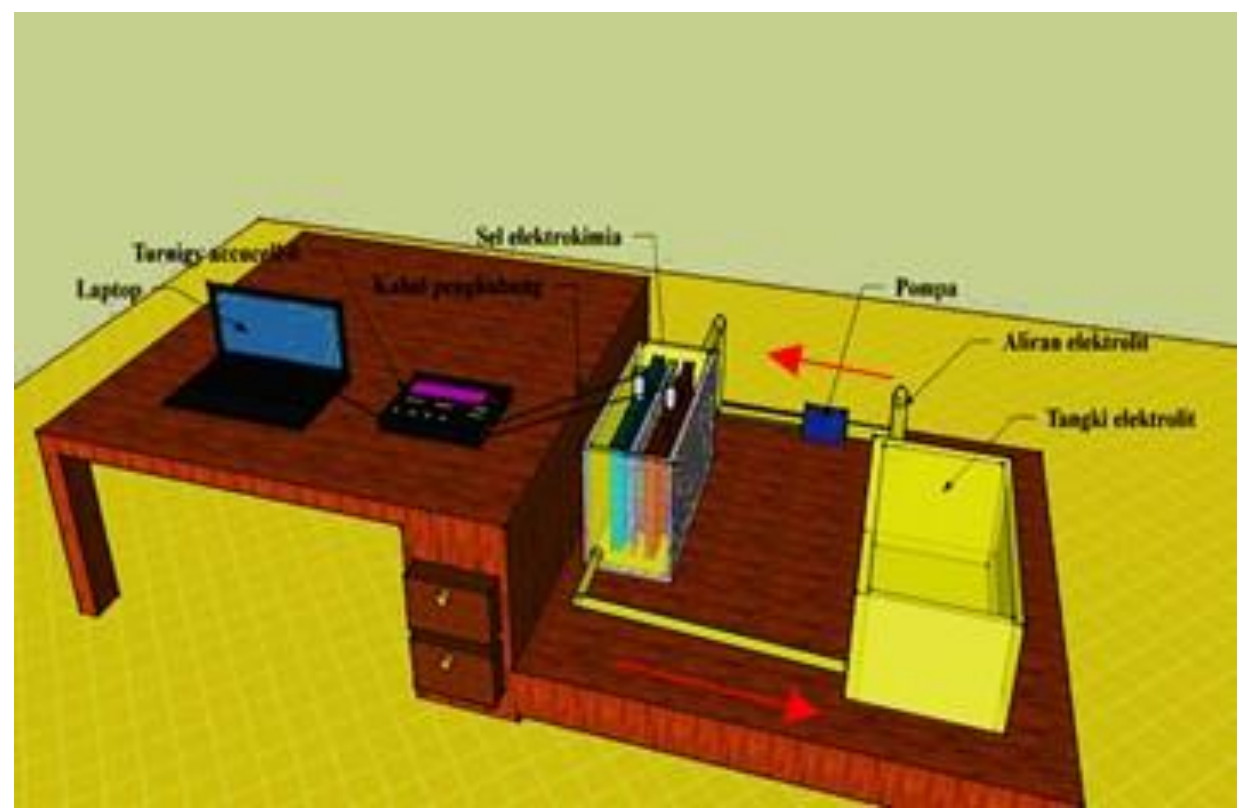

Gambar 1. Skema rangkaian penelitian LARFB variasi laju elektrolit

Arus listrik yang digunakan sebesar 1 A dan volume elektrolit asam sulfat tanki sebesar 600 $\mathrm{mL}$ dengan konsentrasi 30\%. Selama pengujian pengisian-pengosongan baterai dibantu dengan software ChargeMaster 2.02 dan pengolahan data dilakukan dengan bantuan software webplotdigitizer dan excel. Pengujian baterai di lakukan persiklus yakni pengisian sampai penuh dan pengosongan hingga mencapai tegangan terendahnya. Turnigy accucell- 6 telah secara otomatis mengatur tegangan maksimum pengisian $2,4 \mathrm{~V}$ persel dan arus akan diputus pada proses pengosongan saat tegangan mencapai $1,8 \mathrm{~V}$. Hal ini dikarenakan menurut literatur yang ada teganga kinerja baterai asam timbal sebesar 1,8-2,4 V [14-15].

Pada penelitian ini dilakukan 4 buah variasi kelajuan elektrolit. Kelajuan elektrolit dikontrol oleh adaptor yang disambungkan dengan pompa peristaltik. Hubungan tegangan pompa dan kelajuan alir seperti pada tabel 1 .

Tabel 1. Korelasi tegangan adaptor pompa peristaltik terhadap kelajuan aliran elektrolit pada sistem baterai asam timbal sel tunggal.

\begin{tabular}{cccc}
\hline $\begin{array}{c}\text { Nama } \\
\text { Baterai }\end{array}$ & Tegangan Pompa (V) & $\begin{array}{c}\text { Kelajuan aliran elektrolit } \\
(\mathbf{m L / m n t )}\end{array}$ & $\begin{array}{c}\text { Konsentrasi } \\
\text { Elektrolit (\%) }\end{array}$ \\
\hline LARFB 1 & 4,5 & 45 & 30 \\
\hline LARFB 2 & 6,0 & 77 & 30 \\
\hline LARFB 3 & 9,0 & 90 & 30 \\
\hline LARFB 4 & 12,0 & 105 & 30 \\
\hline LARFB 5 & 4,5 & 45 & 40 \\
\hline LARFB 6 & 6,0 & 77 & 40 \\
\hline LARFB 7 & 9,0 & 90 & 40 \\
\hline LARFB 8 & 12,0 & 105 & 40 \\
\hline
\end{tabular}

*LARFB $=$ Lead Acid Redox Flow Battery Variasi 1 


\section{HASIL DAN PEMBAHASAN}

Hasil luaran software ChrageMaster 2.02 pengujian baterai LARFB1 dengan konsentrasi elektrolit 30\% dan penggunaan arus listrik konstan 1 A dan laju elektrolit sebasar $45 \mathrm{~mL} / \mathrm{mnt}$ dapat dilihat pada gambar 2. Tampak bahwa sistem menejemen baterai dapat melakukan record data berupa tegangan kapasitas dan arus listrik terhadap waktu. Adapun suhu baterai tidak dapat di record oleh sistem namun bisa menggunakan termometer luar. Menurut Danang Adiyoga, 2019 dalam penelitiannya diketahui bahwa terdapat perubahan suhu pada sel baterai saat pengisian-pengosongan dimana suhu naik saat pengosongan baterai dilakukan dan turun saat pengisian dilakukan [17].

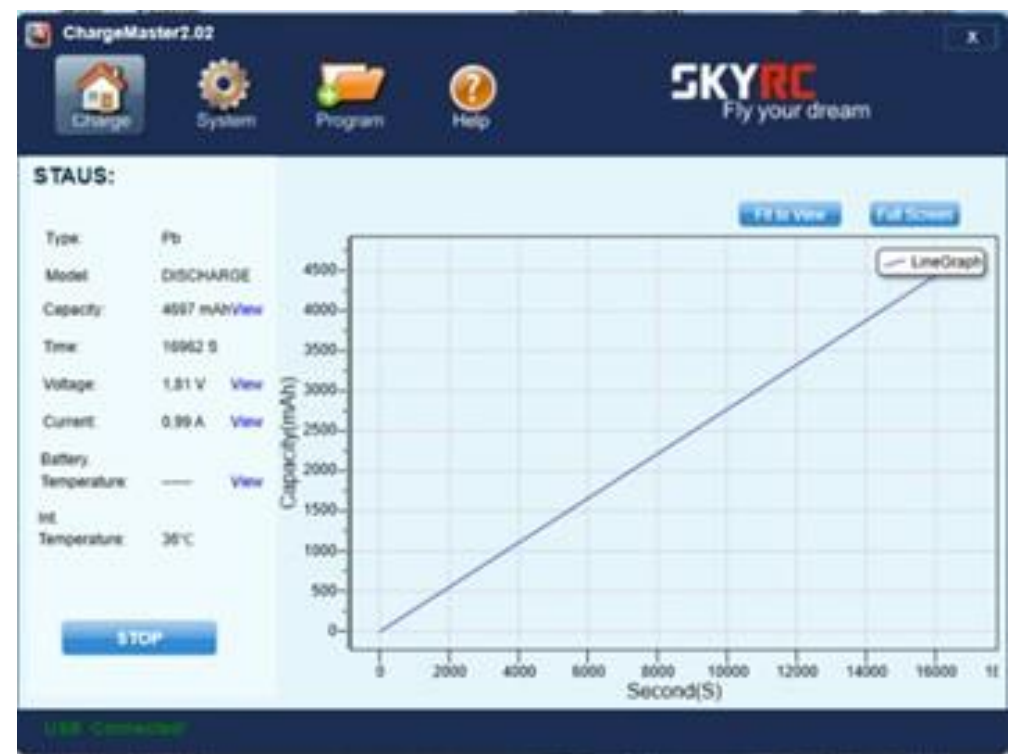

Gambar 2. Tampilan software ChargeMaster 2.02 berupa data karakteristik baterai sebagai fungsi waktu.

Grafik pada gambar 2 bagian kanan menunjukkan kapasitas/muatan baterai sebagai fungsi waktu pada proses pengosongan (discharge) $1 \mathrm{~A}$ (terbaca $0,99 \mathrm{~A}$ di tampilan software pad akhir record) menunjukkan bahwa baterai asam timbal yang dibuat dapat dilakukan pengosongan hingga 16962 detik atau setara dengan kapasitas $4697 \mathrm{mAh}$. Artinya baterai asam timbal yang dibuat sudah memiliki muatan yang bisa dilepas tanpa perlu dilakukan pengisian muatan terlebih dahulu. Hal ini terjadi sebagai akibat adanya reaksi spontan antara kedua elektroda dengan larutan elektrolit asam sulfat. Reaksi spontan ini mengubah elektroda negatif $\mathrm{Pb}$ menjadi $\mathrm{PbSO} 4$ dan elektroda positif $\mathrm{PbO} 2$ menjadi $\mathrm{PbSO} 4$ dan air. Proses selanjutnya setelah pengosongan awal adalah pengisian baterai dengan memberikan arus 1 A pada sistem yang menyebabkan tegangan naik secara cepat dan konstan saat mencapai 2,4 V. Pada tegangan ini pengisian dikatakan telah mencapai tegangan tertinggi dan arus listrik terlihat menurun secara cepat untuk mempertahankan tegangan tersebut yang mengakibatkan laju pengisian muatan menjadi menurun seperti yang terlihat pada gambar 3 . 


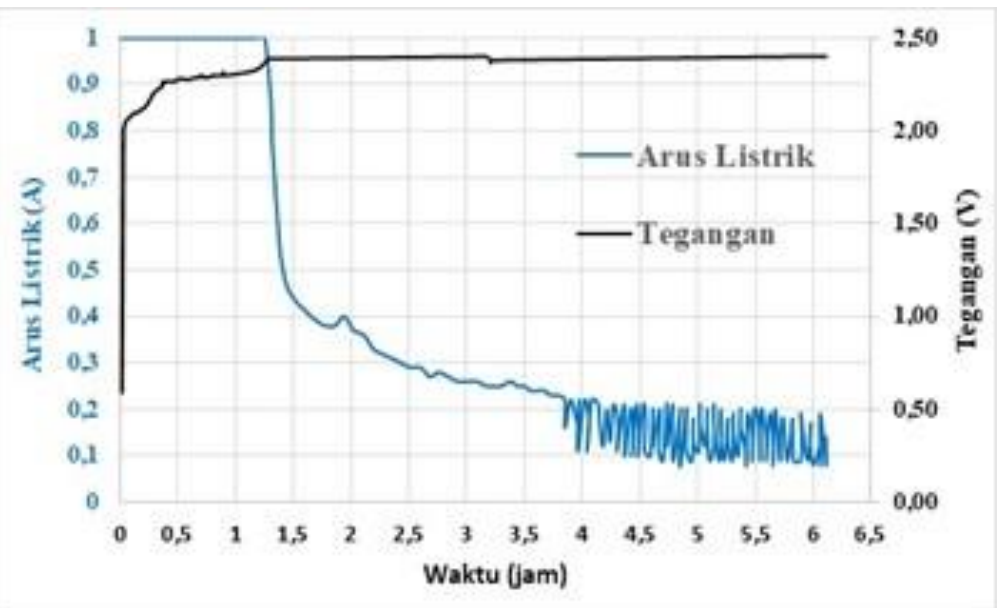

Gambar 3. Grafik arus Listrik (biru/kurva primer) dan tegangan (hitam/kurva sekunder) terhadap waktu pada baterai LARFB1 siklus 1 .

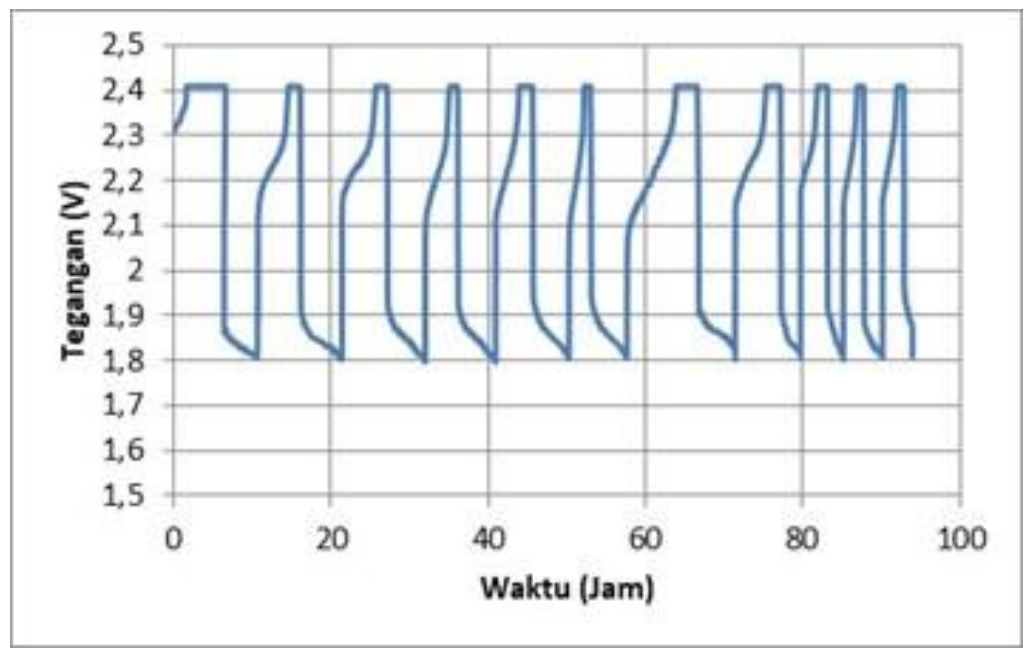

Gambar 4. Grafik tegangan terhadap waktu pengisian-pengosongan 11 siklus baterai dinamis asam timbal konsentrasi $\mathrm{H}_{2} \mathrm{SO}_{4} 30 \%$ dengan kelajuan alir sebesar $45 \mathrm{~mL} / \mathrm{mnt}$.

Selama proses pengisian dan pengosongan pada kelajuan alir elektrolit $45 \mathrm{~mL} / \mathrm{mnt}$ diperoleh grafik tegangan pengisian dan pengosongan yang mirip (tegangan bergerak dari 1,8 $\mathrm{V}$ hingga $2,4 \mathrm{~V}$ ) yang menunjukkan bahwa baterai mampu diisi ulang dengan baik. Perbedaan yang terjadi selama sebelas siklus adalah luasan grafik pengisian pengosongan yang mengindikasikan jumlah muatan yang tersimpan berbeda-beda. Nilai kapasitas baterai dihitung berdasarkan nilai rata-rata pengisian dan nilai rata-rata pengosongan.

Grafik yang mirip juga diperoleh pada variasi kelajuan alir elektrolit $77 \mathrm{~mL} / \mathrm{mnt}, 90 \mathrm{~mL} / \mathrm{mnt}$ dan $105 \mathrm{~mL} / \mathrm{mnt}$ dimana proses pengisian dan pengosongan dapat dilakukan dengan rentang tegangan pengisian 2,01 V sampai $2,40 \mathrm{~V}$ dan rentang tegangan pengosongan 2,08 $\mathrm{V}$ hingga $1,80 \mathrm{~V}$. Hasil lain yang diperoleh adalah jumlah siklus pengisian dan pengosongan semakin sedikit sebelum baterai menunjukkan gejala kerusakan seperti yang ditunjukkan pada gambar 5a hingga 5c. Tampak pada gambar 5 bahwa semakin besar laju elektrolit menunjukkan bahwa semakin besar laju aliran elektrolit maka umur baterai semakin menurun, hal ini berkaitan dengan keadaan elektroda yang terkikis bila kelajuan alir melebihi batas kelajuan tertentu. Pada penelitian ini, semua kelajuan alir elektrolit $45 \mathrm{~mL} / \mathrm{mnt}$ pada 4 siklus pertama menunjukkan 
waktu pengisian dan pengosongan yang hampir sama yakni sekitar 40 jam kecuali pada laju alir elektrolit $77 \mathrm{~mL} / \mathrm{mnt}$ dikarenakan proses pengisian pada siklus1 dan siklus 2 yang lebih lama. Sementara itu tanda-tanda baterai mengalami ketidaknormalan terjadi pada siklus yang memiliki luas grafik yang kecil atau durasi pengisian-pengosongan yang cepat.
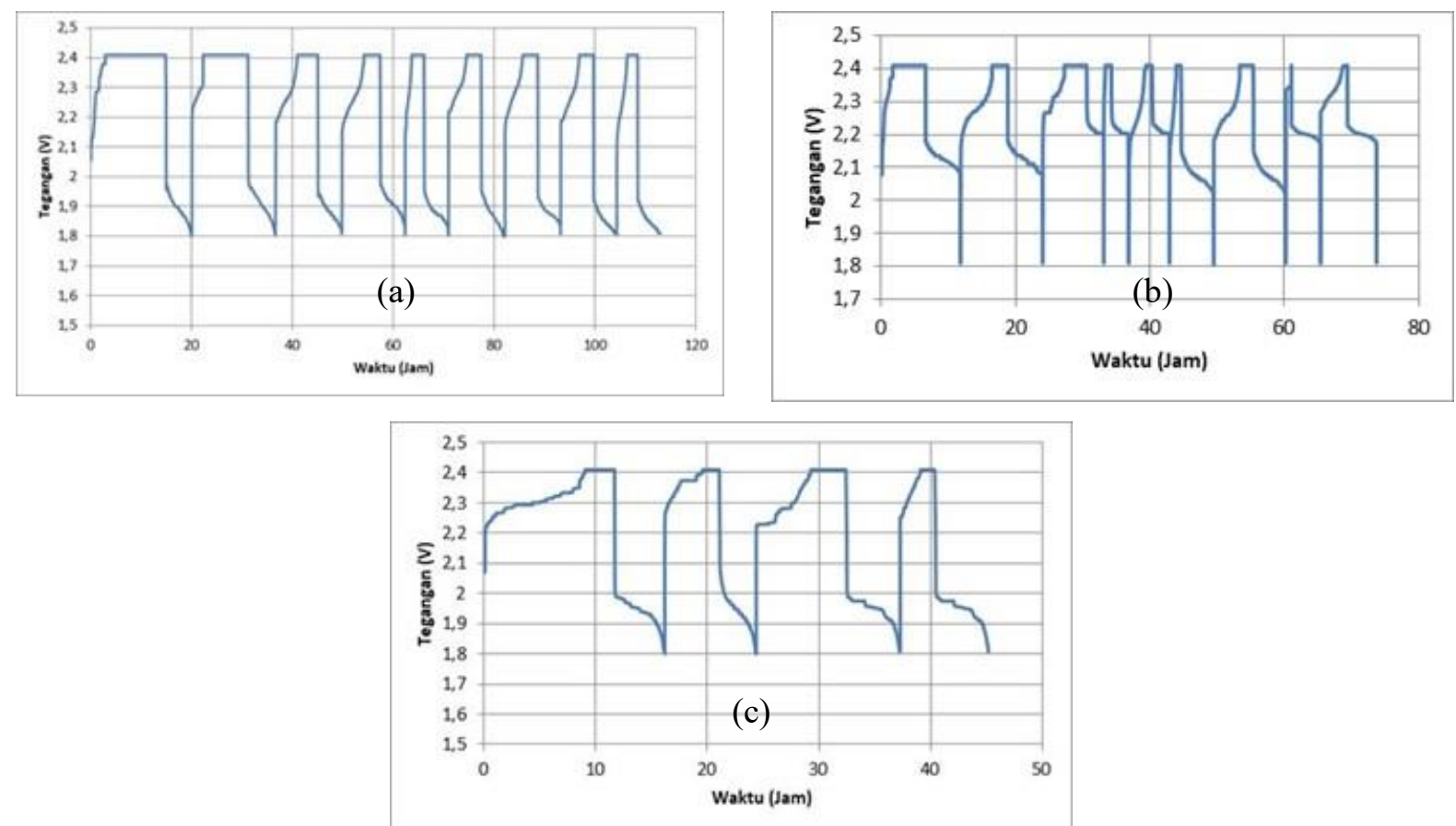

Gambar 5. Grafik tegangan terhadap waktu pengisian-pengosongan beberapa siklus baterai dinamis asam timbal konsentrasi $\mathrm{H} 2 \mathrm{SO} 4$ 30\% dengan kelajuan alir sebesar (a) $77 \mathrm{~mL} / \mathrm{mnt}$, (b) $90 \mathrm{~mL} / \mathrm{mnt}$ dan (c) $105 \mathrm{~mL} / \mathrm{mnt}$.

Tabel 2 memberikan informasi bagaimana dinamika kapasitas pengisian dan pengosongan baterai LARFB dengan konsentrasi 30\% berbeda-beda untuk setiap siklus pengisian dan pengosongan. Pengisian baterai memiliki deviasi dengan rentang $1,7 \%-46 \%$ dari nilai rataratanya sedangkan pada pengosongan relatif stabil dengan rentang deviasi $0,7 \%-22 \%$. Baterai LARFB 2 memiliki kapasitas yang paling stabil dan paling tinggi dari segi kapasitas pengisian dimana memiliki rentang deviasi pengisian 2,6\% - 27\% dan rentang deviasi pengosongan $0,3 \%$ - 5,1\%. Sementara itu baterai dengan kapasitas pengosongan terendah ada pada perlakuan LARFB 4 dengan hanya mampu mengeluarkan kapasitas rata-rata sebesar $3834 \mathrm{mAh}$ dan deviasi pengisian setiap siklus yang besar. Secara nilai kapasitas rata-rata LARFB 1 dan LARFB 3 merupakan baterai dengan kapasitas pengosongan lebih besar dari pada kapasitas pengisian. Fenomena ini terjadi dikarenakan pada proses pengosongan dengan elektrolit mengalir memungkinkan terjadinya pengikisan pada material aktif elektrode sehingga menginisiasi reaksi kimia spontan antara elektroda dengan elektrolit. Pada reaksi kimia spontan elektroda $\mathrm{Pb}$ berubah menjadi $\mathrm{PbSO} 4$ yang berupa padatan dan menempel pada elektroda menyebabkan adanya lapisan $\mathrm{PbSO} 4$ yang bersifat isolator dan menghambat reaksi spontan dengan lapisan di dalamnya. Namun dengan adanya elektrolit mengalir ini menyebabkan lapisan $\mathrm{PbSO} 4$ ini tidak mampu menempel dengan baik dan sebagian justru mengikuti aliran elektrolit sehingga lebih banyak material aktif yang melakukan reaksi spontan menyebabkan 
semakin banyaknya kapasitas baterai. Kapasitas pengosongan terbaik diperoleh pada LARFB 3 pada siklus 1 dan siklus 2 sebesar 5211 mAh dengan rata-rata kapasitas pengosongan sebesar $5062 \mathrm{mAh}$.

Tabel 2. Kapasitas Baterai LARFB konsentrasi elektrolit 30\% dengan berbagai variasi laju alir elektrolit.

\begin{tabular}{lcccccc}
\hline \multirow{2}{*}{ Jenis Baterai } & \multirow{2}{*}{ Status } & \multicolumn{5}{c}{ Kapasitas Baterai Tiap Siklus (mAh) } \\
\cline { 3 - 7 } & & 1 & 2 & 3 & 4 & rata-rata \\
\hline LARFB 1 & $\mathrm{C}^{*}$ & 2478 & 4643 & 4903 & 3488 & 3878 \\
\hline LARFB 1 & $\mathrm{D}$ & 4471 & 4812 & 4940 & 4697 & 4730 \\
\hline LARFB 2 & $\mathrm{C}$ & 6410 & 3971 & 5801 & 5589 & 5443 \\
\hline LARFB 2 & $\mathrm{D}$ & 4923 & 5138 & 4649 & 4885 & 4899 \\
\hline LARFB 3 & $\mathrm{C}$ & 2424 & 6028 & 4596 & 5016 & 4516 \\
\hline LARFB 3 & $\mathrm{D}$ & 5211 & 5211 & 4912 & 4912 & 5062 \\
\hline LARFB 4 & $\mathrm{C}$ & 6686 & 2984 & 6168 & 2682 & 4630 \\
\hline LARFB 4 & $\mathrm{D}$ & 4015 & 2986 & 4167 & 4167 & 3834 \\
\hline
\end{tabular}

$* \mathrm{C}=$ Charging (Pengisian);

$\mathrm{D}=$ Discharging (Pengosongan)

Berdasarkan Gambar 6 dapat diketahui bahwa baterai LARFB1, LARFB 2, dan LARFB 3 berhasil memiliki kapasitas pengisian yang lebih kecil dibandingkan dengan kapasitas pengosongan dan hanya baterai LARFB 4 yang memiliki kapasitas pengisian lebih kecil dibandingkan kapasitas pengosongan. LARFB1, LARFB 2, dan LARFB 3 merupakan sebuah keanehan karena seharusnya kapasitas pengosongan lebih kecil dibandingkan dengan kapasitas pengisian baterai.

Pada baterai LARFB 4 kejadian ini tidak terjadi karena kelajuan elektrolit yang sangat besar yakni $105 \mathrm{~mL} / \mathrm{mnt}$ membuat kekuatan ikatan mekanik bahan elektrode yang dibuat dengan cara kompaksi tidak mampu menahan tekanan alir elektrolit sehingga elektrode mudah rusak yang mengakibatkan elektroda tidak mampu menyimpan muatan dengan baik.

Pada eksperimen lanjutan dengan menggunakan konsentrasi elektrolit $40 \%$ dapat diketahui bahwa baterai dapat dilakukan pengisian dan pengosongan hingga beberapa siklus dengan baik seperti terlihat pada gambar 7. Tingginya konsentrasi elektrolit membuat reaksi redoks yang terjadi semakin banyak dan mengasilkan lebih banyak muatan pada baterai selain menyebabkan tergerusnya elektroda semakin cepat yang mengakibatkan elektroda cepat rusak diindikasikan dari grafik yang cenderung mepet atau durasi pengisian-pengosongan yang relatif lebih pendek. Proses rusaknya elektroda lebih dominan sehingga membuat kapasitas baterai lebih kecil bila dibandingkan dengan baterai dengan konsentrasi 30\%. Kapasitas pengisian LARB 5, LARB 6, LARB 7 dan LARB 8 berturut-turut adalah 3554 mAh, $2021 \mathrm{mAh}, 1562 \mathrm{mAh}$ dan $2820 \mathrm{mAh}$, sedangkan untuk pengosongan bernilai $2910 \mathrm{mAh}, 5090 \mathrm{mAh}, 3146 \mathrm{mAh}$ dan $1404 \mathrm{mAh}$. Nilai ini jauh inferion dibandingkan dengankapasitas baterai dengan konsentrasi 30\%. Baterai terbaik dari segi kapasitas pada variasi ini adalah baterai LARFB 6 dengan kelajuan alir $77 \mathrm{~mL} / \mathrm{mnt}$. Baterai LARFB 5, LARFB 6 dan LARFB 7 memiliki kapasitas pengisian lebih kecil dari pengosongannya sedangkan LARFB 8 terjadi hal sebaliknya. Semakin tinggi laju alir elektrolit membuat baterai gampang rusak. 

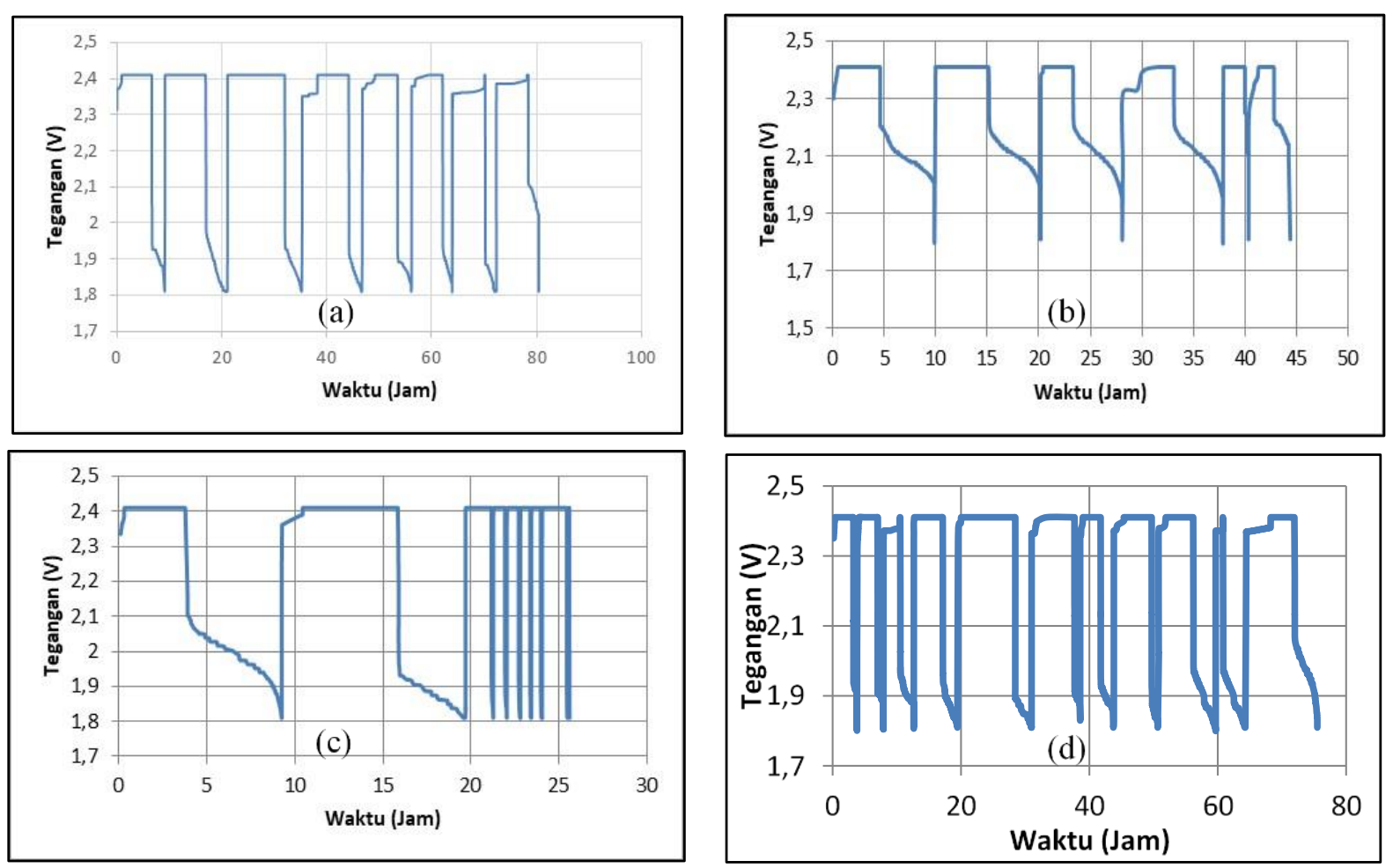

Gambar 7. Grafik tegangan terhadap waktu pengisian-pengosongan beberapa siklus baterai dinamis asam timbal konsentrasi $\mathrm{H}_{2} \mathrm{SO}_{4} 40 \%$ dengan kelajuan alir sebesar (a) $45 \mathrm{~mL} / \mathrm{mnt}$, (b)

$77 \mathrm{~mL} / \mathrm{mnt}$, (c) $90 \mathrm{~mL} / \mathrm{mnt}$ dan (d) $105 \mathrm{~mL} / \mathrm{mnt}$.

\section{KESIMPULAN}

Telah berhasil dibuat baterai redoks asam timbal (LARFB) dengan menggunakan elektrolit $\mathrm{H}_{2} \mathrm{SO}_{4}$ $30 \%$ dan $40 \%$ dan dilakukan uji pengisian-pengosongan beberapa siklus sebelum menunjukkan tandatanda kerusakan. Kelajuan elektrolit $77 \mathrm{~mL} / m n t$ menghasilkan kapasitas pengisian dan pengosongan yang paling baik sedangkan kelajuan $90 \mathrm{~mL} / m n t$ dan $105 \mathrm{~mL} / m n t$ membuat kapasitas baterai menurun dan elektrode mudah rusak karena tidak mampu menahan tekanan akibat kelajuan elektrolit. Performa baterai dengan konsentrasi 30\% lebih baik bila dibandingkan dengan konsentrasi $40 \%$ dari segi kurva tegangan dan nilai kapasitas baterai.

\section{SARAN}

Perlu dilakukan percobaan serupa dengan kelajuan eletrolit lebih rendah di bawah 40 $\mathrm{mL} /$ menit secara terkontrol dan pengujian elektroda menggunakan XRD, SEM EDX untuk mengetahui mikrostruktur elektroda.

\section{DAFTAR PUSTAKA}

Bob Dudley. (2019). BP Statistical Review of World Energy: The 68th edition (London : BP p.1.c)

Yudiatono dkk. (2018). Outlook Energi Indonesia : Energi Berkelanjutan untuk Transportasi Darat (Jakarta : BPPT)

T. Nguyen and R. F. Savinell. (2010). Flow Batteries Electrochem. Soc. Interface Fall, 19(3), 54-56.

Satriady Aditya, Wahyu Alamsyah, Aswad Hi Saad and Sahrul Hidayat. (2016). Pengaruh Luas 
Elektroda Terhadap Karakteristik Baterai $\mathrm{LiFePO}_{4}$. Jurnal Materal dan Energi Indonesia, 06, 43-48.

G-J. Hwang, S-W. Kim, D-M. In, D. Y. Lee and C. H. Ryu. (2018). Application of the commercial ion exchange membranes in the all-vanadium redox flow battery. Journal of Industrial and Engineering Chemistry, 60, 360-365.

Kobra Pourabdollah. (2017). Development of electrolyte inhibitors in nickel cadmium batteries .Chemical EngineeringScience, 160, 304-312

Z. Sun dkk. (2017). Spent lead-acid battery recycling in China - A review and sustainable analyses on mass flow of lead. Waste Management, 64(1), 190-201

K. Hassan, Bakhshali M and Razieh A. (2009). Recovery of discarded sulfated lead-acid batteries by inverse charge. Journal of Energy Conversion and Management, 50, 893898.

Wei Zhang dkk. (2018). A low-cost green approach for synthesis of lead oxide from waste lead ash for use in new lead-acid batteries. China Journal of Chemical Engineering xxx $\mathrm{xxx}-\mathrm{Xxx}$

Yun Li, Shenghai Y., Pekka T., Jing H., Fangwen L., Rongbo Z., Yongming C., Chaobo T., Yuejun W., and Ari J. (2019). Novel recycling process for lead-acid battery paste without $\mathrm{SO}_{2}$ generation - Reaction mechanism and industrial pilot campaign. Journal of Cleaner Production, 217, 162-171

Piergiorgio Alotto, Massimo Guarnieri, and Federico Moro. (2014). Redox flow batteries for the storage of renewable energy: a Review Renewable and Sustainable Energy Reviews, 29, 325-335

Nur Khairati, M. Ghufron, and K. Pranata. (2018). Optimasi Kapasitas Baterai Dinamis Asam Timbal (Redox Flow Battery), SMARTICS, 4(2), 44 - 48

C.P. Zhang, S.M. Sharkh, X. Li, F.C. Walsh, C.N. Zhang, and J.C. Jiang. (2011). The performance of a soluble lead-acid flow battery and its comparison to a static lead-acid battery Energy Conversion and Management, 52, 3391-3398

Muhammad Ghufron dkk. (2018). Charging Time Influence on Dynamic Lead Acid Battery Capacity with H2SO4 Electrolyte The 8th Annual Basic Science International Conference: Covarage of Basic Science Toward the World's Sustainability Challenges AIP Conference Proceedings, 2021, 050006

F R Ramadhan, Muhammad Ghufron, Nur Khairati, Y E Setiawan, Masruroh and K B Pranata. (2019). Influence of discharge current on 3 cells dynamic lead-acid batteries performance 9th Annual Basic Science International Conference 2019 IOP Conf. Series: Materials Science and Engineering, (546) 042009 